\title{
On Allen's Teacher Education Reform Rationale and Strategies
}

\author{
Ruiling Lu* \\ Education Department \\ Taiyuan Normal University \\ Jinzhong, China
}

\author{
Jine Chang \\ Department of Information Engineering \\ Jincheng Institute of Technology \\ Jincheng, China
}

\begin{abstract}
Effective education depends on effective teachers, and effective teachers relies on effective teacher education. This paper briefly introduces American educator Dr. Allen's ideas on teacher education reforms. On the basis of analyzing the prevailing problems facing teacher education, such as "standardized" teacher training programs, divergence between teacher education and basic education, lack of institutional collaboration in teacher preparation, strategies addressing these problems are presented, which include promoting a six-year "Bachelor-Master Combination Degree" teacher training model to accelerate the process of teacher professionalism, strengthening the collaboration between colleges of education and academic departments to work out the most reasonable curriculum for the $21^{\text {st }}$ century, and establishing clinical practice system to provide teacher candidates with adequate hands-on field experience so as to prepare them with better teacher qualifications.
\end{abstract}

Keywords_-Allen; Teacher Education; Reform; Strategies

\section{INTRODUCTION}

Dr. Dwight Allen is an outstanding American education reformer, and a reputable international education expert. He served as the consultant of American $37^{\text {th }}$ president Nixon, and worked for many years as the chief technical advisor of UNESCO and UNDP. When he was a director of teacher education office at Stanford University, he invented the worldknown pre-service teacher-training program "Microteaching". When he became the dean of School of Education at University of Massachusetts, he launched a series of radical education reforms, among which are combating institutional racism, giving students the choice to create their own programs, abolishing the traditional grading system, recruiting non-traditional students and students of color, allowing doctoral students to vote as faculty members and participate fully in the governance of the college of education. In his late years, Dr. Allen were actively involved in the cause of international education. He served as an expert and advisor in more than twenty education institutions. He traveled to more than 80 countries, helping these countries train teachers, conduct research projects, undertake education reforms. Dr. Allen has made great contributions to the globalization and multiculturalism in education world wide.

The paper is a result of the research project titled "Research on the Education Philosophy and Practice of American Education Reformer Dr. Allen" (2014-066) sponsored by Shanxi Scholarship Council of China.
Dr. Allen has devoted his whole life to education initiatives and innovations, and teacher education reform is his main research focus and endeavor. This paper exhibits Dr. Allen's criticism on the major problems facing teacher education, and his reform strategies tackling these problems, with the intention to provide some foundation for more and further research in this area.

\section{PROBLEMS FACING TEACHER EDUCATION}

\section{A. "Standardized" Teacher Education Program}

Teachers are awarded the most glorious mission on earth to provide quality citizens for the society. Whether or not teachers can live up to their mission and fulfill their task would largely depend on the success of teacher education program. Therefore, colleges of education plays a critical role in shaping the quality of prospective teaches, and its influence on education as well as on society as a whole is strong and profound.

In the turn of the century, Dr. Allen pointed out that a prevailing problem facing teacher education is the "standardized" teacher training programs. Teacher education programs are remarkably alike in philosophy, curriculum, pedagogy, and even in problems: no regional variations, no college specialties, no learner differences. Dr. Allen said that the "standardized training model" tended to "produce" mediocrity, which would discourage trial-and-errors, explorations, variations, challenges and risks [1]. Under such model, prospective teachers have learned to teach not professionally, not creatively, but ritualistically. This partly accounts for the fact that teachers are often regarded as quasiprofessionals with high probability of replacement.

\section{B. Divergence between Teacher Education and Basic Education}

As a teacher training institute, colleges of education are supposed to provide quality teachers who can meet the expectations of schools. Most schools today define good teachers as those who are skillful at teaching a largely rote memory curriculum, who are good at keeping their classes under control, and who are capable of sending more students to colleges and universities. But can or should teacher education satisfy the needs of schools? The answer is obvious. As we know, education is a future-based profession, so keeping up with time and aiming ahead of time are 
characteristics and requirements of education, and they are also the important qualities that teachers need to equip their students with. According to Dr. Allen, teacher education should prepare teachers for schools that do not exist or should not exist for the time being, which means teacher education must be oriented toward future [2]. Teachers of the future should be prepared to deal with both the minds and the hearts of their students. They must be intellectually curious, motivated to keep up to date on current affairs and aware of social problems and needs. They need know not only how to teach, but also to inspire, guide, and motivate their students. They ought to be eager to learn from life, from the media, from books, from each other, and from their students. Teacher education has the obligation to train prospective teachers to posses such attitudes and qualities, not simply conform to the requirements of schools.

Another area that teacher education finds it hard to satisfy schools is related to the unrealistic expectations of many schools that general elementary school teachers should have mastered all curriculum areas, and secondary school teachers ought to know everything on the subject that they were prepared to teach, and know something in other subjects. In the United States, many elementary school teachers basically teach all courses offered at school, and many secondary teachers, besides teaching their subject courses, need to serve as directors, consultants, or coaches in various extracurricular activities and club. Are there any academic majors that are capable of training such master-of-all experts for schools? In an information age when everything changes so rapidly, knowledge in any subject will soon become outmoded. To help prospective teachers succeed in future profession, they must be prepared to learn on their own and along with their students, to know what and when they do not know and how to learn it. What is more, even if there are teacher education programs that are ambitious and insightful enough to take the challenge, it is impossible to have such a great enterprise accomplished within the four-year undergraduate teacher preparation programs. During the limited period of time, prospective teachers need to finish the required courses in both subject disciplines and pedagogic areas, plus classroom observations, practicum, internship, etc. Such a tight schedule naturally prevents teacher training institutes to prepare masterof-all teachers expected by schools.

\section{Lack of Collaboration between Colleges of Education and Academic Departments}

In U. S. prospective teachers normally spend around twoand-half years taking their academic major courses (say, math, history, English) at academic departments, and one-and-half years taking teacher education courses at colleges of education. As a general proposition, the success of any teacher-training program depends on good cooperation and interaction between colleges of education and other academic departments. Unfortunately, the two institutes seldom have rapport relationship, and the pervasive arguments about whether content or method is more important have been going on and on for decades after decades. Academic departments simply ignore methodology, and they never reward faculty for their involvement in the training of teachers. To make up for this drawback, colleges of education try to integrate some subject area content into their program, but because their faculty generally lack the systematic training in subject disciplines, this approach does not work effectively. In addition, too many faculty members responsible for training teachers are so fond of restraining themselves in the ivory tower, and reluctant to go to schools. They know little of the issues and problems going on at schools, which makes their instruction deviated from real life and short of practical values. To make the matter worse, higher education always places too much emphasis on research in academic discipline, and research productivity has traditionally been the prime criterion for faculty promotion. Such assessment mechanism distracts faculty's attention from teaching and studies of teaching [3].

\section{APPROACHES TO TEACHER EDUCATION REFORMS}

All sorts of problems in teacher education require a radical change, not just piecemeal reform, addressing only symptoms, such as low test score, high dropouts rate, rather than causes. In response to the expectations of schools for "all-around" elementary school teachers and "expert-like" secondary school teachers, Dr. Allen proposed a full preparation of all teachers through a six-year "Bachelor-Master Combination Degree" model. Concerning the never-ending debating over "content" and "method", Dr. Allen suggested that a joint teacher-training mechanism by both colleges of education and academic departments should be put in place. In terms of the "standardized" teacher-training programs that leads to poor teacher quality, Dr. Allen strongly recommended that a close working relationships between schools and colleges of education should be established so that prospective teachers would have more opportunities to pay regular school visits and acquire practical knowledge and skills necessary for their future teaching job.

\section{A. Promoting a Bachelor-Master Combination Degree Model}

Teacher professionalism is a global hot issue today, and it attracts a great deal of attention and research in education arena. Only when teachers are regarded as full professionals, can they enjoy high social status, and their work would have greater significance to the development and progress of the society.

Compared to other professionals (say, lawyers or doctors), teacher training is relatively brief, short, and scarce. It is said that teachers have only one third the professional training of lawyers and less than 20 percent that of doctors [4]. In U. S., teacher education is basically a one-year add-on to undergraduate liberal arts degrees, which is obviously not enough. In order to accelerate the process of teacher professionalism, raise the overall quality of teachers, and meet the needs of the $21^{\text {st }}$ century schools, Dr. Allen proposed that the six-year full preparation of all teachers in combination of bachelor's and master's degree program should be taken to the education of teachers, and that a large proportion of a teacher's preparation should be multidisciplinary [5].

According to Dr. Allen, the most desirable model of training both elementary and secondary school teachers would be to have a comprehensive, multidisciplinary degree at the 
undergraduate level, with some limited opportunity to gain additional depth in one of the disciplines, along with a few introductory courses in education and substantial field experience. At graduate level, prospective teachers would undertake in-depth learning on their concentration, supplemented by more method related courses and field practice.

Here is how this model works. At the undergraduate level, a series of "elementary teaching" majors should be developed as a joint responsibility of the colleges of arts \& sciences and the colleges of education. For their master's degree, elementary school teachers would select one of several concentrations: language arts and social science, math and science, fin arts, practical arts, foreign languages. About twothirds of the two-year graduate program would be academic work in the concentration, and about one-third in education.

Secondary school teachers would choose for their master's degree the subject they are preparing to teach. In this two-year program, about one-third of the requirements could be in education courses, including substantial actual classroom experience. Degree requirements would be developed through consultation among faculties in the academic disciplines, faculties of education, and classroom teachers, which can reflect both national and local standards. Secondary school teachers should be prepared with a multidisciplinary background, in addition to in-depth preparation in the specific subject or subjects they will teach. Given the developmental levels of children and youth, it may be both possible and reasonable for secondary school teachers to share much of their preparation with elementary school teachers.

\section{B. Strengthening Cooperation Between Colleges of Education and Academic Departments}

The ever-lasting universal arguments about whether "content" or "method" is more important is a good proof by itself that that both subject areas and pedagogic matters are equally vital, otherwise the "battle" had long been put to rest, and the "winner" would have come out. Teacher training is the mutual responsibility of both colleges of education and academic departments. The two sides must stop this meaningless and exhausting fighting, and start working side by side to discuss what and how teachers should be trained in order to meet high standards of teacher preparation. It is important for colleges of education to know what teachers will be expected to teach, and it is equally important for academic departments to be given the responsibility to teach the content on which the teachers' professionalism must rest. With this, the entire fabric of education at all levels will be strengthened.

Dr. Allen claimed that academic departments must become more involved in the education of teachers. To make the involvement constructive and effective, at least one faculty member of each academic department offering subject content for the training of teachers should have an elementary or secondary teaching background. Please note that this faculty member have status comparable to his or her colleagues in the department; otherwise, the specific academic issues in the training of teachers will not receive proper consideration.
It is most desirable that a group of professors and scholars from colleges of education and academic departments would come together and collaboratively work out what is reasonable and possible to teach prospective teachers within the available time. Teaching methods courses should be taught jointly by faculty in education and academic disciplines. Even if not jointly taught, there should at least be sufficient communication between the two sides so that academic course related to the preparation of teachers would anticipate an appropriate range of methodologies in their instruction.

Meanwhile, teaching in higher education should receive higher priority. In the view of Dr. Allen, colleges and universities suffer from too much emphasis on research production and letting research be the dominating factor for faculty promotion, which directly leads to neglect of teaching and student learning. Allen insisted that the majority of faculty members at institutions with teacher education programs should be designated as teaching faculty, without research obligations. They should be given time to work with their students and should be rewarded for actively involve their students in the process of learning [6].

\section{Establishing Clinical Practice System for Teacher Candidates}

With the rapid development of teacher professionalism, more and more educators come to realize that a few courses in the methods of teaching is not enough to prepare professionals, and that more field experience is needed to move toward teacher professionalism. Dr. Allen repeatedly addressed the value of clinical experience in teacher education. As he saw it, teacher education must be redefined to include a minimum of one to two years of clinical practice in order for teachers to maintain a high enough standards required of professionals. Teachers should join the ranks of other professionals, such as medical doctors who spend extra time in residency practicing before becoming licenced. This was one of the reasons that Dr. Allen proposed a "six-year bachelor-master combination degree" teacher training program, which gives prospective teachers extra time to gain field experience. To have an effective clinical practice system, three factors must interact smoothly and appropriately.

First, strong administrative suport is a necessity. Efforts must be made at the administrative level to ensure that field practice of teacher candidates is the shared responsibility of schools, school districts, and colleges of education. Schools must have designated personnel to take charge of the field practice for teacher candidates. Each school district should set up a specified office, taking care of the placement of teacher candidates to their requested schools and assigning mentors for them. Colleges of education need have a clinical practice office, resonsible for coordinating the field practice for teacher candidates. The rapport relationship and supportive collaboration of the three parties pave the way for successful field practice of teacher candidates. [7]

Second, effective dual-mentorship is a guarantee. Professors of education cannot be allowed to be isolated from current classroom experience. They must be more closely identified with schools. Too often university professors have 
little contact with real classroom partly due to the research oriented faculty promotion criteria and partly due to the misleading of the "content" over "method" debating. This must change. Dr. Allen strongly recommended that faculty members at colleges of education should be augmented to include clinical professors, that it, practcing teachers who would share their time between the classroom and teacher education. Some of these clinical professors would be located in schools, receiving teacher candidates and providing mentoring and on-site instructions for them. Other clinical professors would be at colleges and universities, either part time or on temporary leave from their classroom positions. It is important that colleges of education choose the best faculty members to serve as clinical professors, and certain qualifications must be satisfied to become clinical professors, say, good command of pedagoy, skillful at teaching, strong sense of responsibility, highly motivated, interested in basic education, having school teaching experience,etc. Besides, there should be detailed specific pre-/while-/post field practice responsibilities for clinical professors, such as various preparation work before field practice starts, designing field practice plans for teacher candidates, observing teacher candidates' classroom teaching and providing feedback for them, evaluating teacher candidates' field practice, paying regular school visits, coordinating any issues related to field practice with school mentors, and so on and so forth [8].

On the other hand, schools also should select senior, experienced, master teachers as the on-site mentors for teacher candidates based on certain qualifications, say, having a master's degree, having received mentoring training or licenced appropriately, having sufficient and successful teaching experience, patient, responsible, willing to do mentoring work. Specific mentoring responsibilities should be presented in written to every on-site mentor.

Third, stable site schools are a must. Teacher professionalism calls for series of rigorous practical training, which may begin with classroom observation, move to supplemental teaching tasks, on to work with individual students, then to limited instructional responsibility in other teachers' classes, then to closely supervised full teaching responsibility. It's obvious that the systematic intense field experience needs continuous support and cooperation from schools. Therefore, it is crucial that long-term close ties should be established between schools and university teacher-training programs.

Dr. Allen particularly liked the idea of "professional development schools" (PDS). He was convinced that this collaborative efforts between students, teacher candidates, school and university faculty, and the community would greatly benefit all learners. Professional development schools are innovative partnership betwen K-12 schools and unviersity teacher educaiton programs. This new evoving teacher training pattern is field-based with rich partnership. It operates at the intersection of pre-service education and in-service teaching, aiming to offer teacher candidates hands-on opportunities to learn to create learner and learning centered instruction. It facilitates the important practices of collaboration, mentoring, and consultation in a collegial and co-operative environment. University professors and school teachers work side by side at PDSs to help teacher candidates acquire the knowledge and skills necessary for teaching profession through regular, intense, systematic on-site training and real life experiences. The partnership between PDSs and colleges of education is similar to that between teaching hospitals and medical schools. Both professions require a great deal of academic theory accompanied by sufficient clinical field practice [9].

\section{CONCLUSION}

The key to effective education is having effective teachers. If the root issues of education are to be addressed, the problems of teacher education cannot be ignored. Given various difficulties and challenges in the preparation of teachers, comprehensive reforms are needed to provide schools with quality teachers. Teacher education cannot be substantially improved until the quality of prospective teachers can be increased and the mandate of the profession better and more cohensively stated. Hopefully Dr. Allen's reform ideology and strategies in teacher education is of some help to stimulate more and further exploration in this area.

\section{ACKNOWLEDGMENT}

Ruiling Lu is very grateful to Dr. Dwight Allen, her doctoral advisor, whose inspiring education philosophy and outstanding reform practice led to this research endeavor. The authors also have immense gratitude to all the members of the research project, whose hard work and collegiality were great assets in implementing the research. Special thanks go to "Shanxi Scholarship Council of China", whose administrative and financial support made this research possible and productive.

\section{REFERENCES}

[1] D. Allen, Schools for a New Century: A Conservative Approach to Radical School Reform. Westport, CT: Praeger Publishers, 1992.

[2] D. Allen, Schools for a New Century: A Conservative Approach to Radical School Reform. Westport, CT: Praeger Publishers, 1992.

[3] R. Lu, Allen's Education Ideology and Reform Practice. Shanghai: Shanghai Jiao Tong University Press, 2017.

[4] D. Allen and W. Cosby. American Schools: The 100 billion Dollar Challenge. New York: Time Warner Trade Publishing (Ipublish.com), 2000.

[5] D. Allen, Schools for a New Century: A Conservative Approach to Radical School Reform. Westport, CT: Praeger Publishers, 1992.

[6] D. Allen, Schools for a New Century: A Conservative Approach to Radical School Reform. Westport, CT: Praeger Publishers, 1992.

[7] J. Greenberg, L. Pomerance, and K. Walsh, Student Teaching in the United States. National Council on Teacher Quality, July 2011:8.

[8] D. Allen and W. Cosby. American Schools: The 100 billion Dollar Challenge. New York: Time Warner Trade Publishing (Ipublish.com), 2000 .

[9] National Council for Accreditation of Teacher Education (NJ), Transforming Teacher Education through Clinical Practice: A National Strategy to Prepare Effective Teachers. Report of the Blue Ribbon Panel on Clinical Preparation and Partnerships for Improved Student Learning. National Council for Accreditation of Teacher Education, 2010:40. 